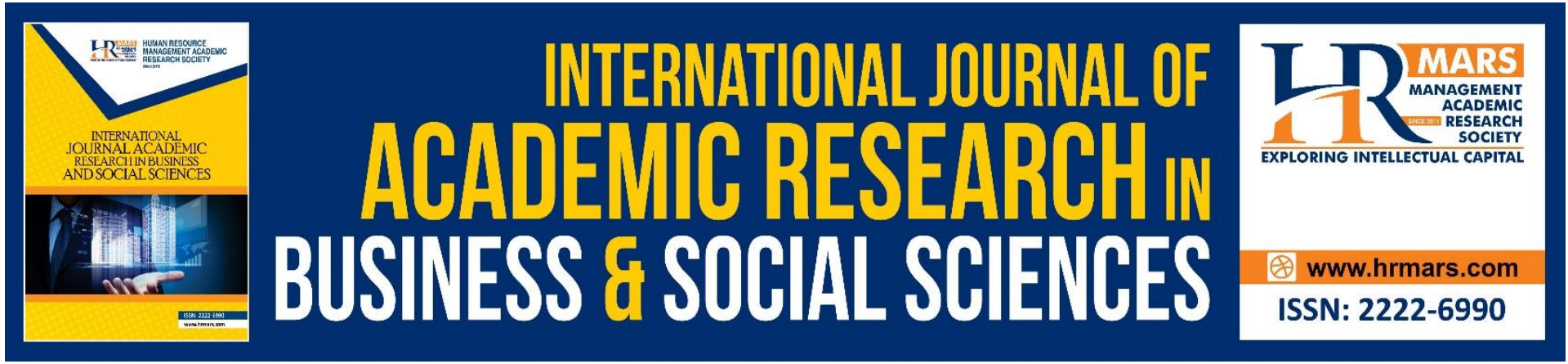

\title{
Relationships between Workload, Role Ambiguity, Work- Family Conflict, Workplace Bullying and Job Stress
}

Dayang Nailul Munna Abg Abdullah, Muhamad Khalil Omar, Noor Azura Dahalan, Ridhawati Zakaria, Zaridah Ibrahim

To Link this Article: http://dx.doi.org/10.6007/IJARBSS/v11-i7/10587

DOI:10.6007/IJARBSS/v11-i7/10587

Received: 04 May 2021, Revised: 28 May 2021, Accepted: 20 June 2021

Published Online: 24 July 2021

In-Text Citation: (Abdullah et al., 2021)

To Cite this Article: Abdullah, D. N. M. A., Omar, M. K., Dahalan, N. A., Zakaria, R., \& Ibrahim, Z. (2021). Relationships between Workload, Role Ambiguity, Work-Family Conflict, Workplace Bullying and Job Stress. International Journal of Academic Research in Business and Social Sciences, 11(7), 1257-1268.

Copyright: () 2021 The Author(s)

Published by Human Resource Management Academic Research Society (www.hrmars.com)

This article is published under the Creative Commons Attribution (CC BY 4.0) license. Anyone may reproduce, distribute, translate and create derivative works of this article (for both commercial and non-commercial purposes), subject to full attribution to the original publication and authors. The full terms of this license may be seen at: $\underline{\text { http://creativecommons.org/licences/by/4.0/legalcode }}$

Vol. 11, No. 7, 2021, Pg. 1257 - 1268

Full Terms \& Conditions of access and use can be found at http://hrmars.com/index.php/pages/detail/publication-ethics 


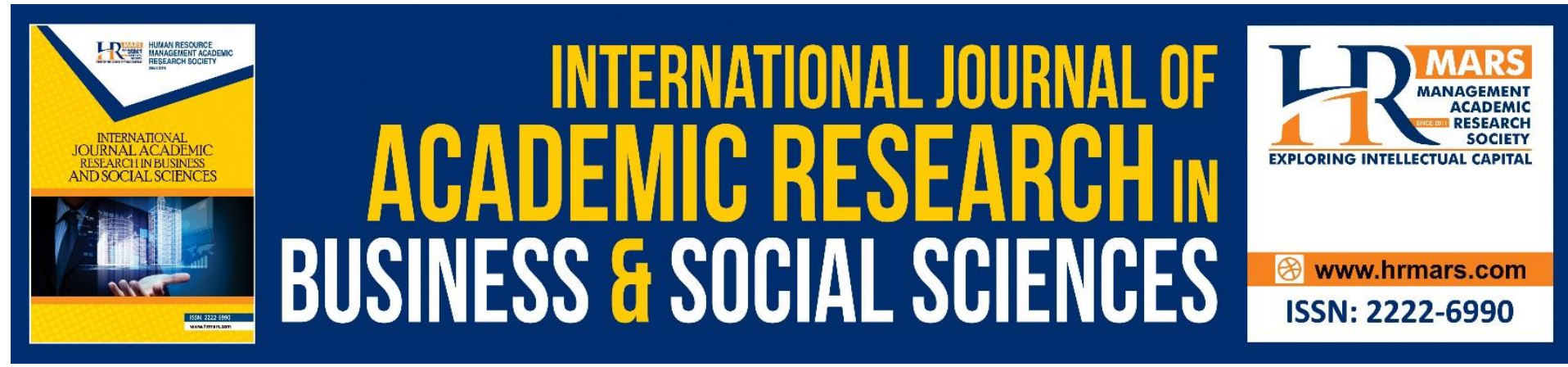

\title{
Relationships between Workload, Role Ambiguity, Work-Family Conflict, Workplace Bullying and Job Stress
}

\author{
Dayang Nailul Munna Abg Abdullah¹, Muhamad Khalil Omar'1, \\ Noor Azura Dahalan¹, Ridhawati Zakaria', Zaridah Ibrahim² \\ ${ }^{1}$ Faculty of Business and Management, Univerisiti Teknologi Mara, Puncak Alam Campus, \\ 42300 Kuala Selangor, Selangor, Malaysia, 'Bahagian Sukan, Kokurikulum dan Kesenian, \\ KPM Aras 1, Blok E13, Parcel E, Pusat Pentadbiran Kerajaan Persekutuan, 62604 Putrajaya, \\ Malaysia \\ Email: nailul@uitm.edu.my,khalil.omar@uitm.edu.my, azuradahalan@uitm.edu.my, \\ ridhawati@uitm.edu.my,zaridah@moe.gov.my
}

\begin{abstract}
Job stress is considered as an important phenomenon that affects an individual, society and organization as a whole. The aim of this research was to investigate the relationship between workload, role ambiguity, work-family conflict, workplace bullying and job stress in Malaysian Palm oil Board (MPOB). In this research, a questionnaire was used as an instrument to collect the data from 140 respondents who were the employees from Grade 29. The respondents were selected using purposive sampling technique. The findings revealed that there was a significant relationship between workload, and work-family conflict with job stress. Meanwhile, regression analysis showed that workload made the strongest unique contribution to explaining the job stress. In conclusion, this research contributed to empirical literature and provided a clear picture about the relationship between workload, role ambiguity, work-family conflict, workplace bullying and job stress.
\end{abstract}

Keywords: Job Stress, Workload, Role Ambiguity, Work-Family Conflict, Workplace Bullying

\section{Introduction}

Typically, stress is a common issue that affects individuals physically, mentally and emotionally which is normally gives a negative outcome in term of behaviour, action, and emotion. According to Saravanan \& Lakshmi (2017), stress is the strain from the conflict between our external environment, leading to physical and emotional pressure). Besides, stress can be positive and negative which depends on the individual's acceptance. In addition, stress consists of positive or negative influences, in which positive stress or eustress can motivate a person towards the action of a new perspective (Mabiza, Conduah \& Mbohwa, 2017). Meanwhile, negative stress or distress affects individual's health such as the person will experience headache, insomnia, and high blood pressure. Generally, most of the stress influence a negative outcome instead of a positive outcome to a person. Only a few are considered to be healthy for an organization (Kaur \& Sharma, 2016). Moreover, job stress 
consists of two dimensions which are physiological stress that can cause headache, migraine, and fatigue to a person. Meanwhile, psychological stress can lead to anger, tension, and anxiety (Sheraz et al., 2014).

Bharathi \& Gupta (2017) claimed that job stress is a condition whereby employees' knowledge, skills, and abilities do not equivalent with the organizational needs. Driven by the massive changes in the business world and stiff competition, employees face the challenges in order to meet the expectation from employers. According to the Chairman of National Institute of Occupational Safety and Health (NIOSH), Tan Sri Lee Lam Thye, he highlighted on the impact of work stress towards mental health and psychosocial factors which affect the efficiency, productivity, and output of any enterprise (NIOSH, 2016). He also added that employee performance, frequent illness, absenteeism, accidents and staff turnover are all affected by employees' mental health status. Therefore, both employers and employees should take this job stress issue seriously. Most importantly, the employer must identify the factors that contribute to job stress so that they can act accordingly in order to reduce this problem.

Therefore, the researchers aim to investigate the factors of workload, role ambiguity, workfamily conflict and workplace bullying that may influence job stress. Hopefully, this study will provide a better understanding to not only Malaysia Palm Oil Board (MPOB), but also to other employers in order to handle this job stress issue efficiently.

\section{Literature Review Job Stress}

According to Babatunde (2013), job stress is a world-wide issue that associated with health matters, work performance, and individual well-being. Nowadays, the increased in the problem due to the job stress is not only affected the employees' work but also influence employees' family (Wani, 2013). For instance, the employee who is unable to cope with the stress at workplace sometimes bring this problem at home and this affects their family. In fact, stress that arises lead to high work related problem in the organization (Bashir \& Ramay, 2010). Based on Mabiza, Conduah \& Mbohwa (2017) research findings, there was a tremendous change in a work environment today that was derived from the innovation of technology, customer's demand and valuable human capital. Consequently, all those changes actually influence the pattern of every occupation and living (Sakkomonsri \& Kaewboonchoo, 2016).

In addition, job stress does not influence individual's physical and mental health only, but also brings cost to the organization (Safaria, Othman \& Wahab, 2010). Moreover, problems of psychological, physiological, and behaviour that arise from job stress can affect employee's health. For instance, Wani (2013) stated that the problem of psychological are depression, anger, anxiety, and tension. Besides, there was a research stated that negative emotions such as depression and anxiety were derived from the employee's stress (Yaacob \& Long, 2015). In fact, stress survey conducted by Ismail \& Noor (2016) indicated that more respondents were suffered from health problems such as insomnia, depression, and hypertension due to the higher workloads.

\section{Workload}

Too much works to be performed by employees that are beyond their capabilities may lead to job stress. The employees might experience fatigue that could hinder the employees and organization productivity (Islam, Uddin \& Hasan, 2017). In this context, fatigue can influence 
the employee's workflow process in which it can affect the employee's ability to make wise decisions, and can result in a lack of awareness and slower reactions to situations. Based on the previous research findings, the result showed that heavy workload can have detrimental effects on the organization as a whole, and it is one of the highest stress determinants that leads to employees' fatigue. Most importantly, both stress and fatigue that occur need to be managed accordingly because these can affect the employees and organizational performance. Due to rapid changes of business today, the job responsibilities are getting higher which require the employees to complete their works in a short period of time. As a result, employees tend to experience stress and anxiety, which may lead to workplace accidents, conflicts, poor performance, job dissatisfaction and turnover intention.

\section{Role Ambiguity}

Based on the findings in a study conducted by Sakkomonsri \& Kaewboonchoo (2016) among ambulance nurses in Bangkok, Thailand, it was found that role ambiguity had a significant relationship with job stress. For instance, employees tend to experience job stress when they are unclear with their job roles and responsibilities. Poor clarification by the employer regarding the expectation of job assigned can create an ineffective working enviroment. Hence, the employer should discuss and clarify the job responsibilities with the employees so that they know what is expected of them at work. Clarification in terms of role and duties of employees is vital in order to reduce stressful situations due to role ambiguity. Furthermore, a study conducted by Dhankar (2015) in banking sector discovered that employees faced high role of ambiguity because of lack of clarity about their roles and responsibility. This factor gives a huge impact to the employees in many aspects such as changes in behaviour, attitude and actions. In addition, role ambiguity can cause problem to employee's health which can affect the performance and productivity of employee and organization as a whole.

\section{Work-Family Conflict}

Despite the challenges faced in today's working world, ideal balance need to be achieved between a person's working life and private life. In this respect, people are fighting towards balancing between work and family in order to avoid any conflicts that may affect personal psychological and physical health. Work-family conflict arises when the incompatible of demand between career and family seems to create a personal pressure to the employees as they try to balance the two roles that need to be performed simultaneously (Jamadin et al., 2015). As a consequence, the pressure experienced by the employees will contribute to a stress at the workplace. In addition, work-family conflict can be divided into three types of conflict namely behavior-based, time-based and strain-based conflicts (Armstrong et al., 2015). The behavior-based conflict refers to incompatible between specific behaviors required by one role with the behavioral norms of another role; time-based conflict occurs when time devoted to the requirements of one role makes it difficult to fulfill requirements of another; and strain-based conflict is defined as stress arising in one role is carried or transferred to the other role, with the consequent strain symptoms (Greenhaus \& Beutell, 1985). Based on previous research, it was claimed that strain-based work-family conflict, behavior-based work-family conflict, and family-work conflict were significantly related to job stress. However, according to Armstrong, Atkin-Plunk \& Well (2015), time-based workfamily conflict was not significantly related to job stress. 


\section{Workplace Bullying}

Workplace bullying is considered as an unpleasant behavior performed by an employee with the intention to harm others. This includes negative behavior that offends or humiliates an employee, often in front of others. In general, workplace bullying is always associated with job stress. It is due to repeated actions that distract individual emotional and physical. In particular, there are two types of workplace bullying namely work-related bullying and person-related bullying. Work-related bullying entails negative behaviors that are directed at the target's professional role and his or her ability to carry out work proficiently. Meanwhile, person-related bullying includes negative behaviors that are predominantly demeaning for the target personally (Notelaers \& Einarsen, 2013). Based on the findings in a study conducted by Taniguchi et al (2016) in Japan which involved workers from welfare facilties for elderly, it was revealed that person-related bullying was significantly and positively associated with the psychological and physical stress reaction. Moreover, there was a significant relationship between workplace bullying and job stress that involved employees of private banks in Lahore, Pakistan (Faran, 2018). Therefore, the organization must take corrective actions in order to reduce the impact of workplace bullying by introducing several methods such as clarify the role of employees, conduct company activities and developing anti-bullying policies as a guideline to overcome workplace bullying (Rajalakshmi \& Gomathi, 2015).

\section{Research Methodology}

This research utilized a quantitative research method in order to determine the relationship between workload, role ambiguity, work-family conflict, and workplace bullying with job stress. The population of this study involved all the supporting employees (non-executive) Grade 29 in eight (8) divisions of MPOB with various positions such as administrative assistant, financial administrative assistant, administrative officer assistant, financial officer assistant and senior administrative assistant. This category of employees was chosen because of their job responsibilities are considered as important in order to help the executive level to achieve the organization's strategic goals. In this respect, the total population of this study was 184 and the sample size was 123 (Krejcie \& Morgan, 1970). Besides, this research used a questionnaire as a research instrument to collect information from the respondents and the results were presented in numerical form. The questionnaire was divided into six (6) sections which represented the demographic profile of respondents, job stress, workload, role ambiguity, work-family conflict and workplace bullying. Hence, a five-point of Likert scale was used in order to determine the rating value or response from respondents. The scale range are from 1 (strongly disagree), 2 (disagree), 3 (neutral), 4 (agree) and 5 (strongly disagree) with the particular statement. In particular, the researchers applied purposive sampling technique because it focuses on particular characteristics of a population that are of interest, which will best enable researchers to answer the research questions.

Two methods of collecting data were used by the researchers namely primary and secondary data. A primary data an original data source, that is one in which the data are collected firsthand by the researcher for a specific research purpose or project (Sekaran \& Bougie, 2011). For instance, the primary data of this study was the data that was collected from MPOB employees using a survey questionnaire. Meanwhile, secondary data is the data that has been collected in the past by someone else but made available for others to use. This data had been gathered and recorded by someone else but being utilized by other researchers for another purpose (Sundram, Atikah, Rohani, Nazura, Akmal \& Krishnasamy, 2016). Hence, secondary data used in this study were journals, books, articles and websites. 
In this research, 140 set of questionnaires were handed over to the HR Personnel of MPOB. A sufficient time was given to the respondents to fill up the questionnaires with minimal interference by the researchers. Furthermore, the researchers took approximately seven (7) working days to gather all the completed questionnaires. Fortunately, all the respondents gave utmost cooperation towards this research. Once all the data had been collected, a software program called Statistical Package for Social Science version 22.0 (SPSS) was used to analyze the data. In this study, descriptive analysis was used to analyze the demographic variables such as gender, age, race, marital status and length of services. Moreover, reliability test was conducted to measure the consistency and stability of the research instrument (Sekaran \& Bougie, 2011). In this research, the most commonly used coefficient in reliability analysis is known as Cronbach's alpha, which is used to measure the internal consistency of items in a survey instrument. In addition, multiple regression analysis was used as a statistical analysis procedure that expands linear regression by including more than one independent variable in an equation to understand their association with a dependent variable.

\section{Findings and Discussion}

\section{Demographic Profile of the Respondents}

Based on Table I, $55.7 \%$ of the respondents were male, followed by $44.3 \%$ of the respondents were female. Majority of the respondents were from the " $31-40$ years old" group with a percentage of $39.3 \%$. Meanwhile, the smallest group of respondents came from the " $51-60$ years old" group with a percentage of $11.4 \%$. Besides, most of the respondents were Malay $(99.3 \%)$, followed by other races with a percentage of $0.7 \%$. In addition, the findings also revealed that $77.9 \%$ of the respondents were married, followed by $20.7 \%$ of them were single and $1.4 \%$ of the respondents belonged to "Others" group. Moreover, most of the respondents served MPOB for more than 10 years with a percentage of $32.1 \%$. 


\begin{tabular}{|c|c|c|c|}
\hline \multicolumn{2}{|c|}{ Demographic Profile } & \multirow{2}{*}{$\begin{array}{l}\text { Frequency } \\
78\end{array}$} & \multirow{2}{*}{$\begin{array}{l}\text { Percentage } \\
\text { (\%) } \\
55.7\end{array}$} \\
\hline Gandor & Male & & \\
\hline Sender & Female & 62 & 44.3 \\
\hline \multirow{4}{*}{ Age } & $\begin{array}{l}19-30 \\
\text { years old }\end{array}$ & 50 & 35.7 \\
\hline & $\begin{array}{l}31-40 \\
\text { years old }\end{array}$ & 55 & 39.3 \\
\hline & $\begin{array}{l}41-50 \\
\text { years old }\end{array}$ & 19 & 13.6 \\
\hline & $\begin{array}{l}51-60 \\
\text { years old }\end{array}$ & 16 & 11.4 \\
\hline \multirow{4}{*}{ Race } & Malay & 139 & 99.3 \\
\hline & Chinese & 0 & .0 \\
\hline & Indian & 0 & .0 \\
\hline & Others & 1 & .7 \\
\hline \multirow{3}{*}{$\begin{array}{l}\text { Marital } \\
\text { Status }\end{array}$} & Married & 109 & 77.9 \\
\hline & Single & 29 & 20.7 \\
\hline & Others & 2 & 1.4 \\
\hline \multirow{5}{*}{$\begin{array}{l}\text { Length } \\
\text { of } \\
\text { Service }\end{array}$} & $\begin{array}{l}\text { Less than } 1 \\
\text { year }\end{array}$ & 6 & 4.3 \\
\hline & $1-3$ years & 32 & 22.9 \\
\hline & $4-6$ years & 24 & 17.1 \\
\hline & $7-9$ years & 33 & 23.6 \\
\hline & $\begin{array}{l}\text { More than } \\
10 \text { years }\end{array}$ & 45 & 32.1 \\
\hline
\end{tabular}

\section{Results of Reliability Analysis}

Table II showed the Cronbach's alpha value for each variable. Job stress with 7 question items had a Cronbach's alpha value of 0.910 which was considered as excellent (Manerikar \& Manerikar, 2015). Next is workload with 7 question items which had a Cronbach's alpha value of 0.898 which was indicated as good since it was more than 0.80 . For role ambiguity, 6 question items were used and the Cronbach's alpha value was 0.874 which was indicated as good as well. Furthermore, work-family conflict and workplace bullying had Cronbach's alpha values of 0.868 and 0.892 respectively which were considered as good. 
TABLE II. RESULTS OF RELIABILITY ANALYSIS

\begin{tabular}{|l|l|l|l|}
\hline Variable & $\begin{array}{l}\text { No. of } \\
\text { Items }\end{array}$ & $\begin{array}{l}\text { Cronbach's } \\
\text { Alpha }\end{array}$ & $\begin{array}{l}\text { Degree of } \\
\text { Reliability }\end{array}$ \\
\hline Job Stress & 7 & 0.910 & Excellent \\
\hline Workload & 7 & 0.898 & Good \\
\hline $\begin{array}{l}\text { Role } \\
\text { Ambiguity }\end{array}$ & 6 & 0.874 & Good \\
\hline $\begin{array}{l}\text { Work- } \\
\text { Family } \\
\text { Conflict }\end{array}$ & 7 & 0.868 & Good \\
\hline $\begin{array}{l}\text { Workplace } \\
\text { Bullying }\end{array}$ & 7 & 0.892 & Good \\
\hline
\end{tabular}

\section{Results of Regression Analysis}

Based on Table III, there was a significant and strong relationship between workload and job stress (Agunbiade \& Ogunyinka, 2013) in which $\beta=0.551, p=0.00, p<0.05$. This indicated that the higher the workload, the higher the job stress. Therefore, the hypothesis $1(\mathrm{H} 1)$ which stated that there is a significant relationship between workload and job stress was accepted. This finding was supported by Islam, Uddin \& Hasan (2017) in which it was clearly revealed in their study that workload was the higher stressor that leads to employees' stress due to excessive works. Besides, employees may experience fatigue if job stress was not carefully managed. Similarly, it was found that work overload had a significant positive relationship with job stress (Sheraz, Wajid, Sajid, Qureshi \& Rizwan, 2014). Work overload occurs due to the incompatibility of several aspects such as inadequate resources and time constraint during the completion of the task which lead to job stress. Therefore, employees will feel the pressure especially if they were unable to complete the task in the allotted time period.

Furthermore, this research finding also revealed that there was no significant relationship between role ambiguity and job stress $(~ B=0.007, p=0.918, p>0.05)$. Therefore, hypothesis 2 $(\mathrm{H} 2)$ that stated there is a significant relationship between role ambiguity and job stress was rejected. One of the reasons why role ambiguity had no significant relationship with job stress might be due to employees were clear about the expectations from their own roles. Good clarification with regards to the duties and responsibilities were given to the employees, thus help to reduce job stress. In addition, effective communication between both employer and employees help to ensure any clarification about the jobs assigned is clear. In fact, comprehensive clarification towards any issues can help to reduce stress in the workplace (Sakkomonsri \& Kaewboonchoo, 2016). Furthermore, this research findings showed that most of the respondents have served MPOB for more than 10 years. Hence, they are able to understand their roles and any requirements that are necessary in order to accomplish certain task.

Additionally, there was a significant but moderate relationship between work-family conflict and job stress (Agunbiade \& Ogunyinka, 2013) in which $ß=0.203, p=0.26, p<0.05$. This indicated that the higher the work-family conflict, the higher the job stress. Therefore, hypothesis $3(\mathrm{H} 3)$ which stated that there is a significant relationship between work-family conflict and job stress was accepted. According to Jamadin et al (2015), there was a significant relationship between work-family conflict and job stress. This is due to the pressure experienced by employees because of conflicts between work and family demands. Based on the previous research findings, most of the respondents were married and doing extra hours 
of work during weekends which may influenced job stress. Furthermore, it was found that strain-based work-family conflict, behavior-based work-family conflict, and family-work conflict had positive relationships with job stress (Armstrong, Atkin-Plunk \& Wells, 2015). Therefore, the employer should consider offering flexible work arrangements to help emlpoyees to overcome work-family conflict. For instance, offering flextime, compressed work week, job sharing, and telecommuting.

Moreover, it was clearly showed that there was no significant relationship between workplace bullying and job stress ( $\beta=0.064, p=0.361, p>0.05)$. Therefore, hypothesis $4(\mathrm{H} 4)$ which stated that there is a significant relationship between workplace bullying and job stress was rejected. This finding evidently revealed that workplace bullying was not the major cause of job stress in MPOB. This could be due to most employees show appropriate behaviours that have positive effects on physical and psychological of employees. Besides, the finding clearly indicated that the employees did not feel ignored or excluded and insulted by people at work. Furthermore, negative actions such as threats or sabotage are avoided so that these will not cause stress to the employees.

In addition, as shown in Table III, the R square value was 0.690. Expressed as a percentage, this means that the independent variables which are workload, role ambiguity, work-family conflict and workplace bullying explained 69 percent of the variance in job stress. To assess the statistical significance of the result, it is necessary to look at the table labelled ANOVA. It was clearly revealed that the result reached the statistical significance, $p=0.000(p<0.0005)$. Furthermore, we need to look at the largest beta value to compare the contribution of each independent variable. In this study, the largest beta coefficient was 0.551 ( $p=0.000)$, which was for workload. This means that workload made the strongest unique contribution to explaining the dependent variable, job stress.

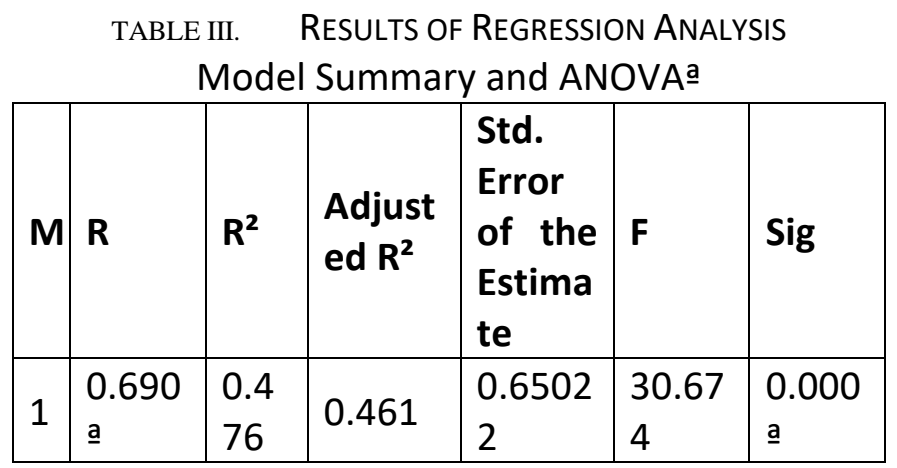

a. Predictors: (Constant), W, RA, WFC, WB 


\begin{tabular}{|c|c|c|c|c|c|c|}
\hline \multicolumn{7}{|c|}{ Coefficientsa } \\
\hline \multirow{2}{*}{\multicolumn{2}{|c|}{ M }} & \multicolumn{2}{|c|}{$\begin{array}{l}\text { Unstandardiz } \\
\text { ed } \\
\text { Coefficients }\end{array}$} & \multirow{2}{*}{$\begin{array}{l}\text { Standard } \\
\text { ized } \\
\text { Coefficie } \\
\text { nts } \\
\text { Beta }\end{array}$} & \multirow[t]{2}{*}{$\mathbf{t}$} & \multirow[t]{2}{*}{ Sig. } \\
\hline & & B & $\begin{array}{l}\text { Std. } \\
\text { Error }\end{array}$ & & & \\
\hline 1 & (C) & $\begin{array}{l}0.70 \\
6\end{array}$ & 0.428 & & $\begin{array}{l}1.64 \\
7\end{array}$ & $\begin{array}{l}0.10 \\
2\end{array}$ \\
\hline & $\mathbf{w}$ & $\begin{array}{l}0.57 \\
2\end{array}$ & 0.093 & 0.551 & $\begin{array}{l}6.13 \\
3\end{array}$ & $\begin{array}{l}0.00 \\
0\end{array}$ \\
\hline & RA & $\begin{array}{l}0.00 \\
9\end{array}$ & 0.086 & 0.007 & $\begin{array}{l}0.10 \\
4\end{array}$ & $\begin{array}{l}0.91 \\
8\end{array}$ \\
\hline & $\begin{array}{l}\text { WF } \\
C\end{array}$ & $\begin{array}{l}0.21 \\
9\end{array}$ & 0.097 & 0.203 & $\begin{array}{l}2.25 \\
2\end{array}$ & $\begin{array}{l}0.02 \\
6\end{array}$ \\
\hline & WB & $\begin{array}{l}- \\
0.06 \\
8\end{array}$ & 0.075 & -0.064 & $\begin{array}{l}- \\
0.06 \\
4\end{array}$ & $\begin{array}{l}0.36 \\
1\end{array}$ \\
\hline
\end{tabular}

a. Dependent Variable: Job Stress

Note: M - Model; C - Constant; W - Workload; RA - Role Ambiguity; WFC - Work-Family Conflict; WB - Workplace Bullying

\section{Conclusion}

Job stress is a common work related problem or issue that needs to be taken seriously by not only employees but also employers. The effects of job stress can be disastrous if it is not carefully managed. For instance, employees will experience fatigue, anxious, depressed, having sleeping difficulties, hard to stay focused and always getting sick. Therefore, the researchers would like to give some recommendations to the employers so that necessary actions can be taken to reduce job stress in the organization. Job redesign is one of the best approaches in order to cope with job stress issue. It focuses on the elements such as task, duties, and responsibilities in a particular job that need to be restructured in order to enhance the motivational level, job satisfaction, performance and productivity among employees. Besides, the employer should provide flexible working schedule to the employees so that they can manage between work and non-work activities appropriately. Other than that, introducing wellness and physical fitness programs can help in maintaining a healthy lifestyle in terms of both physical and mental health.

\section{Acknowledgment}

The authors wish to thank Universiti Teknologi MARA for the funding, and to all respondents who are willing to participate in this research and allowing the dissemination of the findings of this research.

\section{References}

Agunbiade, D. A., \& Ogunyinka, P. I. (2013). Effect of correlation level on the use of auxiliary variable in double sampling for regression estimation. Open Journal of Statistics, 3, 312318. 
Armstrong, G. S., Atkin-Plunk, C. A., \& Wells, J. (2015). The relationship between work-family conflict, correctional officer job stress, and job satisfaction. International Association for Correctional and Forensic Psychology, 1-17.

Babatunde, A. (2013). Occupational stress: A review on conceptualisations, causes and cure. Economic Insights - Trends and Challenges, II (LXV)(2), 73-80.

Bashir, U., \& Ramay, M. I. (2010). Impact of stress on employees job performance: A study on banking sector of Pakistan. International Journal of Marketing Studies, 2(1), 122-126.

Bharathi, T., \& Gupta, D. (2017). Job stress and productivity: A conceptual framework. International Journal of Emerging Research in Management and Technology, 6(8), 393399.

Dhankar, S. (2015). Occupational stress in banking sector. International Journal of Applied Research, 1(8), 132-135.

Faran, R. (2018). Impact of workplace bullying on job performance and job stress. Journal of Management Info, 5(3), 12-15.

Greenhaus, J. H., \& Beutell, N. J. (1985). Sources of conflict between work and family roles. Academy of Management Review, 10, 76-88.

Islam, M. S., Uddin, M. M., \& Hasan, M. R. (2017). Measuring and analyzing job stress and fatigue among workers and its impact on employee productivity in a pharmaceutical factory: A case study. International Conference on Mechanical, Industrial and Materials Engineering, 1-6.

Ismail, N. H., \& Noor, A. (2016). Occupational stress and its associated factors among academician in a research university, Malaysia. Malaysian Journal of Public Health Medicine, 16(1), 81-91.

Jamadin, N., Mohamad, S., Syarkawi, Z., \& Noordin, F. (2015). Work-family conflict and stress: evidence from Malaysia. Journal of Economics, Business and Management, 3(2), 309312.

Kaur, R. P., \& Sharma, P. G. (2016). Stress management in the banking sector. Imperial Journal of Interdisciplinary Research, 2(3), 113-117.

Krejcie, R. V., \& Morgan, D. W. (1970). Determining sample size for research activities. Educational and Psychological Measurement, 30, 607-610.

Mabiza, J., Conduah, J., \& Mbohwa, C. (2017). Occupational role stress on employee performance and the resulting impact: A South African Bank perspective. International MultiConference of Engineers and Computer Scientists, II.

Manerikar, V., \& Manerikar, S. (2015). Cronbach alpha. Aweshkar Research Journal, 14(1), 117-119.

NIOSH. (2016). Promote mental healthcare at the workplace. The Star Online, Retrieved from https://www.thestar.com.my/news/nation/2016/04/03/niosh-promote-mentalhealthcare-at-the-workplace/

Notelaers, G., \& Einarsen, S. (2013). The world turns at 33 and 45: Defining simple cutoff scores for the Negative Acts Questionnaire-Revised in a representative sample. European Journal of Work and Organizational Psychology, 22, 670-682.

Rajalakshmi, M., \& Gomathi, S. (2015). A study on the factors influencing workplace bullying and its impact on employee stress. Mediterranean Journal of Social Sciences, 6(1), 292299.

Safaria, T., Othman, A. B., \& Wahab, M. N. (2010). Religious coping, job insecurity and job stress among Javanese academic staff: A moderated regression analysis. International Journal of Psychological Studies, 2(2). 
Sakkomonsri, J., \& Kaewboonchoo, O. (2016). Factors associated with job stress among ambulance nurses in Bangkok, Thailand. The Bangkok Medical Journal, 12, 33-38.

Saravanan, K., \& Lakshmi, M. K. (2017). A study on stress management among employees in Nationalized Bank, Trichy City. International Journal of Trend in Scientific Research and Development, 1(6), 1220-1230.

Sekaran, U., \& Bougie, R. (2011). Research Methods for Business: A Skill-Building Approach. Chichester: J. Wiley \& Sons.

Sheraz, I. A., Wajid, M., Sajid, M., Qureshi, W. H., \& Rizwan, M. (2014). Antecedents of job stress and its impact on job performance and turnover intentions. International Journal of Learning and Development, 4(2), 204-226.

Sundram, V. P. K., Atikah, S. B., Rohani, M., Nazura, M. S., Akmal, A. O., \& Krishnasamy, T. (2016). Research Methodology: Tools, Methods and Techniques. Petaling Jaya, Selangor: MLSCA.

Taniguchi, T., Takaki, J., Hirokawa, K., Fujii, Y., \& Harano, K. (2016). Associations of workplace bullying and harassment with stress reactions: A two-year follow-up study. Industrial Health, 54, 131-138.

Wani, S. K. (2013). Job stress and its impact on employee motivation: a study of a select commercial bank. International Journal of Business and Management Invention, 2(3), 13-18.

Yaacob, M., \& Long, C. S. (2015). Role of occupational stress on job satisfaction. Mediterranean Journal of Social Sciences, 6(2), 81-87. 